\title{
Peri-Operative Chemotherapy for Bladder Cancer: A Survey of Providers to Determine Barriers and Enablers
}

\author{
Melanie Walker ${ }^{\mathrm{a}, \mathrm{d}}$, R. Christopher Doiron ${ }^{\mathrm{c}}$, Simon D. French ${ }^{\mathrm{d}, \mathrm{e}}$, Kelly Brennan ${ }^{\mathrm{a}}$, \\ Deb Feldman-Stewart ${ }^{\mathrm{a}, \mathrm{b}}$, D. Robert Siemens ${ }^{\mathrm{b}, \mathrm{c}}$, William J. Mackillop ${ }^{\mathrm{a}, \mathrm{b}, \mathrm{d}}$ \\ and Christopher M. Booth ${ }^{\mathrm{a}, \mathrm{b}, \mathrm{d}, *}$ \\ ${ }^{a}$ Division of Cancer Care and Epidemiology, Queen's University Cancer Research Institute, \\ Queen's University, ON, Canada \\ ${ }^{\mathrm{b}}$ Department of Oncology, Queen's University, ON, Canada \\ ${ }^{\mathrm{c}}$ Department of Urology, Queen's University, ON, Canada \\ ${ }^{\mathrm{d}}$ Department of Public Health Sciences, Queen's University, ON, Canada \\ e School of Rehabilitation Therapy, Queen's University, ON, Canada
}

\begin{abstract}
.
Background: Utilization of chemotherapy for patients with muscle-invasive bladder cancer (MIBC) is low. In earlier qualitative work we used the Theoretical Domains Framework (TDF) to determine barriers and enablers of chemotherapy use. In this project we aimed to determine the prevalence of these barriers and enablers in Canadian physicians.

Methods: Practicing Canadian urologists, medical oncologists (MOs) and radiation oncologists (ROs) participated in a specialty-specific web-based quantitative survey to assess potential barriers and enablers to chemotherapy use. Survey questions were developed that were thematically mapped to TDF domains. Logistic regression was used to identify TDF domains associated with high referral/use of chemotherapy.

Results: 110 urologists, 47 MOs and 43 ROs completed the survey; response rates were 20\%, 35\% and 31\% respectively. The mean reported survival gain associated with neoadjuvant chemotherapy (NACT) was 9\%, 8\%, and 7\% for urologists, MOs, and ROs respectively. Among participating urologists, the TDF domains 'social and professional role' $(\mathrm{OR}=16.5,95 \% \mathrm{CI}$ 4.6-59.2), 'social influences' ( $\mathrm{OR}=5.7,95 \%$ CI 2.4-13.4) 'beliefs about consequences' ( $\mathrm{OR}=4.9,95 \% \mathrm{CI} 1.8-13.3)$ and 'memory, attention and decision-making' $(\mathrm{OR}=0.50,95 \% \mathrm{CI} 0.27-0.91)$ were associated with MO referral rates. Among MOs, the TDF domains 'behavioural regulation', 'social influences', and 'social and professional role' were associated with greater use of chemotherapy $(p<0.05)$. No TDF domains were associated with RO referral to MO.

Conclusions: We have identified several factors associated with referral/use of chemotherapy for MIBC. Optimization of multidisciplinary patient care needs to be considered when designing future interventions to close the gap between evidence and practice.
\end{abstract}

Keywords: Bladder cancer, quality of care, chemotherapy, surgery, knowledge translation

\footnotetext{
*Correspondence to: Dr. Christopher Booth, Division of Cancer Care and Epidemiology, Queen's University Cancer Research Institute, 10 Stuart Street, Kingston, ON, K7L 3N6, Canada.
} Tel.: +1 613533 6895; Fax: +1 613533 6794; E-mail: boothc@
kgh.kari.net. 


\section{INTRODUCTION}

International guidelines recommend neoadjuvant chemotherapy (NACT) for patients with muscleinvasive bladder cancer (MIBC) [1-3]; emerging evidence suggests that adjuvant chemotherapy (ACT) provides comparable benefit $[4,5]$. We have recently described practice patterns in Ontario, Canada [6, 7]. Only $6 \%$ and $22 \%$ of patients in Ontario received NACT or ACT during 1994-2008, respectively; $16 \%$ and $39 \%$ of patients were referred to MO for consideration of NACT/ACT. Similar findings have been described elsewhere [8-11]. These data identify upstream barriers at the urologist and downstream at the MO.

Limited literature exists that identifies barriers and enablers to chemotherapy use for bladder cancer with most studies only describing self-reported practice patterns [7, 12-14]. A recent survey of 125 urologic oncologists found that the strongest patient factors associated with use of NACT was clinical T3/4 disease [15]. The same study also found that surgeons who work at centres where medical oncologists are strong proponents of NACT are more likely to discuss this treatment option with patients. We recently undertook a qualitative study using a knowledge translation (KT) framework to identify knowledge, attitudes and beliefs among urologists, MOs and radiation oncologists (ROs) about NACT/ACT (In Press, Can Urol Assoc J). The predominant enablers to the use of chemotherapy included: the presence of chemotherapy 'champions', routine referral to MO, and system-level factors that optimize multidisciplinary care. The predominant barriers included: a lack of confidence in the magnitude of benefit associated with NACT/ACT and inadequate multidisciplinary collaboration.

Use of a knowledge translation (KT) conceptual framework can guide future intervention studies [16, 17]. The Theoretical Domains Framework (TDF) is a comprehensive framework to identify barriers and enablers of implementing evidence into practice. The TDF can facilitate design of KT interventions as it offers broad coverage of potential change pathways [18].

We undertook this quantitative study to determine the prevalence of barriers and enablers among practicing urologists, MOs and ROs. Barriers and enablers identified within the relevant theoretical domains can subsequently be mapped to appropriate implementation interventions in an effort to increase chemotherapy utilization.

\section{METHODS}

\section{Study design and participants}

Results from an earlier qualitative study (In Press, Can Urol Assoc J) informed the development of a cross-sectional survey for the three specialist groups. All practicing urologists, MOs and ROs who treat patients with bladder cancer in Canada were invited to participate in the electronic survey (June 2016). The survey was distributed to all Canadian urologists and MOs/ROs that treat bladder cancer. The survey was distributed electronically using Fluid Surveys@software. A modified approach of Dillman's Total Design Method [19] was used to maximize response rates. The study was approved by the Research Ethics Board of Queen's University.

\section{Survey design and content}

Survey design was based on thematic analysis of our recently completed qualitative study. Question development was based on targeted health behaviours: (1) Are urologists referring patients to MO for NACT/ ACT?; (2) Are MOs treating patients with NACT/ACT?; and (3) Are ROs referring patients to MO for NACT/ACT if not already done by urology? The surveys included questions informed by domains of the TDF [17] (Appendix 1) pertaining to (a) the knowledge, attitudes and beliefs of the clinicians about referral/use of NACT/ACT; and (b) the potential barriers and enablers of chemotherapy delivery. Responses to the majority of survey questions were in the form of categorical (yes/no; multiple choice) and ordinal variables (5-point Likert scale).

Questions were developed for each TDF domain. TDF domains are not mutually exclusive and thus a survey question may be mapped to more than one relevant TDF domain. Responses to ordinal survey questions were collapsed into three categories for analysis purposes: strongly disagree/disagree, neutral, strongly agree/agree. In addition, a composite summary mean score of all questions relevant to each of the identified TDF domains was created for univariate analysis [20, 21]. Higher scores are more conducive to achieving the targeted health behaviours (i.e. increased referral/use of NACT/ACT). Participants were excluded from the summary score for a given TDF domain if there were missing values on any questions within that domain. This approach was chosen since we had few study respondents with missing values ( $16 / 200 \mathrm{had} \geq 1$ missing value $)$ and we 
Table 1

Survival estimates from urologists, medical oncologists and radiation oncologists for a hypothetical case scenario

\begin{tabular}{|c|c|c|c|c|}
\hline \multicolumn{5}{|c|}{ ESTIMATED 5 YEAR OVERALL SURVIVAL (\%) } \\
\hline \multicolumn{5}{|c|}{ CASE 1: MIBC Patient Pre Cystectomy With No Clinical Node Involvement ${ }^{\wedge}$} \\
\hline & & Cystectomy alone & $\begin{array}{c}\text { NACT + } \\
\text { Cystectomy } \\
\end{array}$ & $\begin{array}{c}\text { Cystectomy + } \\
\text { ACT }\end{array}$ \\
\hline Urologists & Mean & 55 & 64 & 57 \\
\hline \multirow{2}{*}{$\mathrm{N}=110$} & Median & 50 & 65 & 55 \\
\hline & Range & $(25-85)$ & $(20-95)$ & $(20-85)$ \\
\hline Medical & Mean & 49 & 57 & 53 \\
\hline Oncologists & Median & 50 & 57 & 53 \\
\hline $\mathrm{N}=47$ & Range & $(10-80)$ & $(30-90)$ & $(20-82)$ \\
\hline Radiation & Mean & 51 & 58 & 55 \\
\hline Oncologists & Median & 50 & 57 & 55 \\
\hline $\mathrm{N}=43$ & Range & $(20-75)$ & $(30-85)$ & $(20-80)$ \\
\hline All & Mean & 53 & 61 & 56 \\
\hline Specialists & Median & 50 & 60 & 55 \\
\hline $\mathrm{N}=200$ & Range & $(10-85)$ & $(20-95)$ & $(20-85)$ \\
\hline
\end{tabular}

$\wedge^{\wedge}$ 65 year old man presents to the Emergency Room with hematuria. Cystoscopy and biopsy shows evidence of muscle-invasive urothelial carcinoma. Staging CT scan of the chest/abdomen/pelvis and bone scan do not show any evidence of metastatic disease (imaging suggests T3 N0 disease). The patient has minimal co-morbidity, normal renal function, and is willing to follow your recommendations. What treatment options would you consider recommending for this patient?

could not assume responses were missing at random $[20,21]$.

The surveys also included questions about contraindications for chemotherapy and the presentation of a hypothetical case. Open-ended survey questions were used to ask participants about the greatest achievements and challenges in delivering chemotherapy.

The surveys were developed by a multidisciplinary team with expertise in the treatment of bladder cancer and expertise in survey methodology/implementation science.

\section{Statistical analysis}

We used the following questions to classify respondents as low or high adopters of NACT/ACT: Urologists - 'Of the last 10 patients that you have seen with MIBC, how many of them did you refer to medical oncology for a discussion about chemotherapy?'; MOs - 'Of the last 10 MIBC patients that you have seen, how many of them did you treat with NACT or ACT)?'; ROs - 'Of the last 10 MIBC patients that you have seen, how many would NOT already have been referred to medical oncology by urology?'; and 'Of those MIBC patients not referred by urology, how many did you refer to medical oncology for a discussion about chemotherapy?'. Respondents whose reported values were greater than or equal to the median were classified as high adopters. Logistic regression was used to identify TDF domains associated with high adoption of NACT/ACT referral/use in practice. Results were considered statistically significant at $p$-value $<0.05$. All analyses were performed using SAS version 9.4 (SAS Institute, Cary, NC).

\section{RESULTS}

\section{Study participants}

Survey response rates were $20 \%$ for urologists (110/562), 36\% for MOs (47/131), and 31\% for ROs (43/139). The proportion of respondents who treated $>10$ MIBC patients/year were 34\% (37/110 urologists), 47\% (22/47 MOs), and 28\% (12/43 ROs).

\section{Case scenario and survival estimates}

Survival estimates for a hypothetical case of a 60 year old man with clinical T3N0 MIBC are shown in Table 1 . Mean overall survival at 5 years with cystectomy alone was $53 \%, 61 \%$ with NACT and $56 \%$ with ACT. However, as shown in Fig. 1 there is substantial variation within each specialty. Urologists, MOs and ROs reported a mean $9 \%, 8 \%$, and $7 \%$ survival gain with NACT respectively; corresponding mean survival gains with ACT were 2\%, 4\%, and $4 \%$ respectively.

\section{Identified barriers and enablers to NACT/ACT referral/use}

Urologists reported referring a median of $9 / 10$ patients to MO to discuss NACT/ACT. MOs reported 


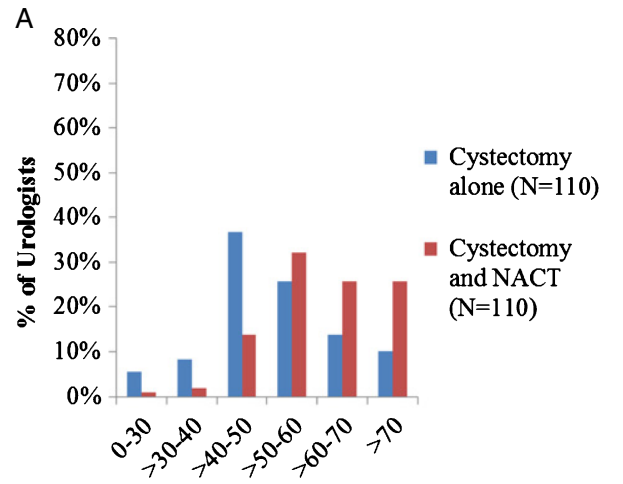

Estimated 5 Year Survival (\%)

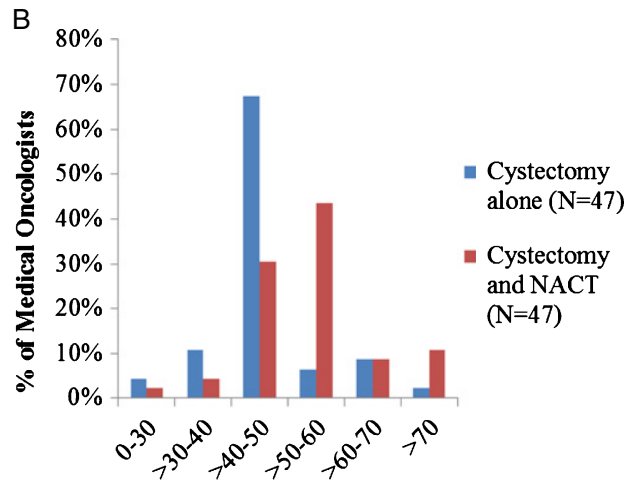

Estimated 5 Year Survival (\%)

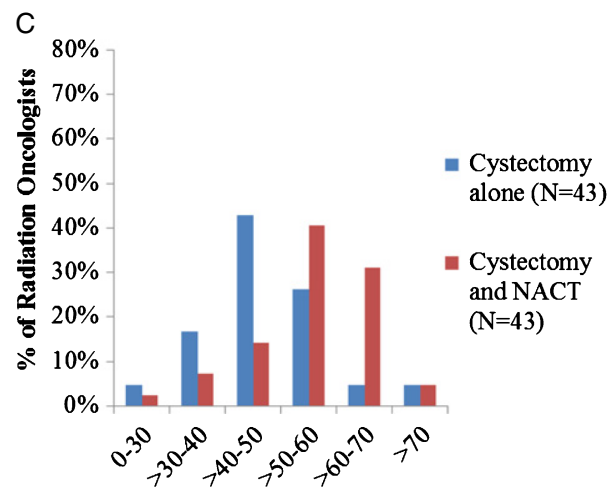

Estimated 5 Year Survival (\%)

Fig. 1. Survival estimates for a hypothetical patient with muscle-invasive bladder cancer treated with cystectomy and/or neoadjuvant chemotherapy as reported by urologists (Panel A), medical oncologists (Panel B), and radiation oncologists (Panel C).

treating a median of 7/10 patients referred for NACT/ ACT. ROs reported that a median of 3/10 MIBC patients seen were not already referred to MO by urology; a median of 2/3 patients were subsequently referred to MO.

Univariate associations between TDF summary domain scores and referral/use of NACT/ACT are found in Table 2. A summary of specialist-specific survey questions and responses organized by TDF domain can be found in Appendices 2-4.

Behaviour 1: Are urologists referring MIBC patients to MO for NACT/ ACT?

TDF domains 'beliefs about consequences' (OR = 4.9, 95\% CI 1.8-13.3), 'social and professional role' $(\mathrm{OR}=16.5,95 \% \mathrm{CI}$ 4.6-59.2) and 'social influences' $(\mathrm{OR}=5.7,95 \%$ CI 2.4-13.4) were all associated with higher rates of referral to MO. Within these domains we highlight pertinent questions and responses. 'Beliefs about consequences': $89 \%$ (94/106) felt confident in the evidence sup- porting NACT, $82 \%(87 / 106)$ felt the magnitude of benefit associated with NACT is important, and $25 \%(27 / 106)$ were concerned about NACT delaying surgery. 'Social and professional role': 46\% (45/97) felt it was their responsibility to select which patients are eligible for chemotherapy and only refer those patients. 'Social influences': 77\% (74/96) reported that patients are generally accepting of chemotherapy. The TDF domain 'memory, attention and decision making' was inversely associated with referral to $\mathrm{MO}$ $(\mathrm{OR}=0.50,95 \% \mathrm{CI} 0.27-0.91)$. Forty-four percent of urologists (45/103) felt confident in determining who was a candidate for chemotherapy.

\section{Behaviour 2: Are MOs treating MIBC patients with NACT/ACT?}

TDF domains 'social and professional role' $(\mathrm{OR}=4.9,95 \%$ CI 1.1-22.0), 'social influences' $(\mathrm{OR}=6.6,95 \%$ CI 1.5-28.6) and 'behavioural regulation' $(\mathrm{OR}=12.2,95 \% \mathrm{CI} 2.0-75.6)$ were associated with increased use of NACT/ACT (Table 3). 'Social 
Table 2

Associations between TDF domains and adoption of chemotherapy across physician specialties for patients with localized muscle-invasive bladder cancer

\begin{tabular}{lccc}
\hline TDF Domain & \multicolumn{3}{c}{ Association with "High Adopter"* of Chemotherapy } \\
& \multicolumn{3}{c}{ OR (95\% CI) * } \\
\cline { 2 - 4 } & Urologists & Medical Oncologists & Radiation Oncologists \\
\hline Beliefs about consequences & $\mathbf{4 . 8 7}(\mathbf{1 . 7 9 - 1 3 . 2 6 )}$ & $2.40(0.47-12.31)$ & $0.37(0.06-2.17)$ \\
Memory, attention, decision-making skills & $\mathbf{0 . 5 0}(\mathbf{0 . 2 7 - 0 . 9 1 )}$ & $1.35(0.52-3.48)$ & $0.66(0.19-2.24)$ \\
Social and professional role & $\mathbf{1 6 . 5 0}(\mathbf{4 . 6 0 - 5 9 . 1 6})$ & $\mathbf{4 . 8 8}(\mathbf{1 . 0 8}-\mathbf{2 2 . 0 3})$ & $0.40(0.09-1.86)$ \\
Environmental context and resources & $1.65(0.72-3.77)$ & $1.15(0.37-3.60)$ & $0.68(0.22-2.11)$ \\
Social influences & $\mathbf{5 . 6 8}(\mathbf{2 . 4 1 - 1 3 . 3 7})$ & $\mathbf{6 . 5 5}(\mathbf{1 . 5 0 - 2 8 . 6 1})$ & $\mathrm{n} / \mathrm{a}$ \\
Behavioural regulation & $\mathrm{n} / \mathrm{a}$ & $\mathbf{1 2 . 2 3}(\mathbf{1 . 9 8}-\mathbf{7 5 . 5 9})$ & $1.33(0.74-2.40)$ \\
Knowledge & $\mathrm{n} / \mathrm{a}$ & $1.24(0.62-2.46)$ & $\mathrm{n} / \mathrm{a}$ \\
Beliefs about capabilities & $0.53(0.27-1.03)$ & $1.25(0.63-2.48)$ & $\mathrm{n} / \mathrm{a}$ \\
\hline
\end{tabular}

*A urologist was defined as a high adopter if they referred a median of $\geq 9 / 10$ MIBC patients to medical oncology for consultation. A medical oncologist was defined as a high adopter if they treated a median of $\geq 7 / 10$ referred MIBC patients with chemotherapy. A radiation oncologist was defined as a high adopter if they referred a median of $\geq 2$ of the last 3 patients that they had seen to medical oncology that that were not already referred by urology. $\mathrm{OR}=$ odds ratio. $\mathrm{CI}=$ confidence interval. $\mathrm{n} / \mathrm{a}=$ no survey questions for the domain. Bolded values indicate statistically significant results $(p<0.05)$.

and professional role': 74\% (35/47) and 83\% (39/47) reported having local urology and MO champions advocating for NACT/ACT; 38\% (18/47) stated that urologists only refer patients they feel are suitable for NACT/ACT. 'Social influences': $87 \%$ (41/47) indicated that patients were generally accepting of chemotherapy. 'Behavioural regulation': 83\% (39/47) felt that urologists routinely refer patients to MO.

\section{Behaviour 3: Are ROs referring MIBC patients to MO for NACT/ACT if not already done by urology?}

Among ROs, no TDF domains were associated with increased referral of MIBC patients to MO for chemotherapy consultation (Table 2). This is likely explained by the fact that, in this study, very few patients (3/10) seen by ROs had not already been referred to $\mathrm{MO}$ for chemotherapy consultation.

\section{Contraindications to chemotherapy}

Reported contraindications to chemotherapy are shown in Table 3. Poor performance status (>ECOG 2), renal insufficiency, and peripheral neuropathy were reported by a majority of respondents as contraindications to NACT/ACT.

\section{System-level barriers and enablers in relation to referral/use of NACT/ACT}

The TDF domain 'environmental context and resources' emerged as a common theme in the open-response question about the greatest achievements/challenges in delivering chemotherapy. Common themes included access to urologists/MOs with genitourinary cancer expertise, multidisciplinary bladder clinics (MBC) and case conferences (MCC); availability of nurse navigator; communication between urology and MO; and accessibility of operating room time. A substantial majority of respondents felt that having MCCs, MBCs, and a mandatory $\mathrm{MO}$ referral policy contributed to greater use of NACT/ACT at their centre (Table 4).

\section{Do provider beliefs guide practice?}

The median magnitude of benefit (i.e. absolute improvement in 5 year OS) associated with NACT was $5 \%$. Providers who reported an estimated effect size of $>5 \%$ were more likely to be refer/deliver chemotherapy compared to providers who reported estimated effect sizes of $<5 \%$ (67\% vs $46 \%, p=0.003$ ). Twenty-three percent of all respondents strongly agreed that magnitude of survival benefit associated with NACT is important; $62 \%$ of these providers were "adopters" of chemotherapy compared to $54 \%$ of providers who did not strongly agree $(p=0.334)$.

\section{DISCUSSION}

This survey explored knowledge, attitudes, and beliefs of urologists, MOs, and ROs in Canada regarding the utilization of NACT/ACT for muscle-invasive bladder cancer. The survey questions were designed 
Table 3

Potential contraindications to neoadjuvant/adjuvant chemotherapy for muscle-invasive bladder cancer as reported by urologists, medical oncologists, and radiation oncologists

\begin{tabular}{lccc}
\hline Potential Contraindication & $\begin{array}{c}\text { Urologists } \\
(\mathrm{N}=106) \\
\mathrm{N}(\%)\end{array}$ & $\begin{array}{c}\text { Medical } \\
\text { Oncologists } \\
(\mathrm{N}=47)\end{array}$ & $\begin{array}{c}\text { Radiation } \\
\text { Oncologists } \\
\mathrm{N}=41)\end{array}$ \\
\hline Patients $>70$ years of age & $7(7 \%)$ & $1(2 \%)$ & $3(\%)$ \\
Patients with cardiovascular disease & $15(14 \%)$ & $13(28 \%)$ & $10(24 \%)$ \\
Patients with peripheral neuropathy & $44(42 \%)$ & $26(55 \%)$ & $15(37 \%)$ \\
Patients with poor ECOG performance status $(>2)$ & $88(83 \%)$ & $46(98 \%)$ & $40(98 \%)$ \\
Patients with renal insufficiency & $91(86 \%)$ & $39(83 \%)$ & $29(71 \%)$ \\
Patients with tinnitus & $25(24 \%)$ & $17(36 \%)$ & $9(22 \%)$ \\
\hline
\end{tabular}

Table 4

System-level enablers to the referral/use of chemotherapy among patients with muscle-invasive bladder cancer

\begin{tabular}{|c|c|c|c|}
\hline $\begin{array}{l}\text { Survey questions related to the TDF Domain } \\
\text { Environmental context and resources }\end{array}$ & $\begin{array}{l}\text { Urologists } \\
\text { No. }(\%)^{*}\end{array}$ & $\begin{array}{l}\text { Medical } \\
\text { Oncologists } \\
\text { No. }(\%)^{*}\end{array}$ & $\begin{array}{l}\text { Radiation } \\
\text { Oncologists } \\
\text { No. }(\%)^{*} \\
\end{array}$ \\
\hline Multidisciplinary case conferences & $(\mathrm{N}=81)$ & $(\mathrm{N}=43)$ & $(\mathrm{N}=39)$ \\
\hline \multicolumn{4}{|l|}{$\begin{array}{l}\text { Our GU multidisciplinary case conferences are helpful } \\
\text { to discuss treatment options for patients with MIBC }\end{array}$} \\
\hline Strongly Agree/Agree & $79 \%$ & $86 \%$ & $85 \%$ \\
\hline \multicolumn{4}{|l|}{$\begin{array}{l}\text { Our GU multidisciplinary case conferences are well } \\
\text { attended by urology }\end{array}$} \\
\hline Strongly Agree/Agree & $77 \%$ & $74 \%$ & $77 \%$ \\
\hline \multicolumn{4}{|l|}{$\begin{array}{l}\text { Our GU multidisciplinary case conferences are well } \\
\text { attended by medical oncology }\end{array}$} \\
\hline Strongly Agree/Agree & $93 \%$ & $100 \%$ & $95 \%$ \\
\hline \multicolumn{4}{|l|}{$\begin{array}{l}\text { Our GU multidisciplinary case conferences are well } \\
\text { attended by radiation oncology }\end{array}$} \\
\hline Strongly Agree/Agree & $90 \%$ & $95 \%$ & $90 \%$ \\
\hline \multicolumn{4}{|l|}{$\begin{array}{l}\text { Our GU multidisciplinary case conferences result in a } \\
\text { larger proportion of MIBC patients receiving } \\
\text { NACT/ACT. }\end{array}$} \\
\hline Strongly Agree/Agree & $67 \%$ & $\mathrm{~N} / \mathrm{A}^{\wedge}$ & $51 \%$ \\
\hline Multidisciplinary bladder clinics & $\mathrm{N}=23$ & $\mathrm{~N}=11$ & $\mathrm{~N}=8$ \\
\hline \multicolumn{4}{|l|}{$\begin{array}{l}\text { Our multidisciplinary clinic for bladder cancer has } \\
\text { resulted in more patients being treated with } \\
\text { NACT/ACT }\end{array}$} \\
\hline Strongly Agree/Agree & $78 \%$ & $82 \%$ & $88 \%$ \\
\hline Nurse Navigator & $\mathrm{N}=61$ & $\mathrm{~N}=32$ & $\mathrm{~N}=28$ \\
\hline \multicolumn{4}{|l|}{$\begin{array}{l}\text { Our institution has a nurse navigator that helps with the } \\
\text { patient referral system }\end{array}$} \\
\hline Yes & $49 \%$ & $50 \%$ & $39 \%$ \\
\hline $\begin{array}{l}\text { Institutional Policy to ensure MIBC patients are seen by } \\
\text { medical oncology, urology and radiation oncology }\end{array}$ & $\mathrm{N}=6$ & $\mathrm{~N}=8$ & $\mathrm{~N}=11$ \\
\hline \multicolumn{4}{|l|}{$\begin{array}{l}\text { More patients with MIBC are receiving NACT/ACT at } \\
\text { our center since we instituted a policy that patients are } \\
\text { to be referred to medical oncology }\end{array}$} \\
\hline Strongly Agree/Agree & $67 \%$ & $6(75 \%)$ & $9(82 \%)$ \\
\hline Medical Oncologists with GU expertise & $\mathrm{N}=66$ & $\mathrm{~N}=42$ & $\mathrm{~N}=39$ \\
\hline \multicolumn{4}{|l|}{$\begin{array}{l}\text { The percentage of MIBC patients at our center who get } \\
\text { NACT/ACT increased after we obtained GU MO } \\
\text { expertise }\end{array}$} \\
\hline Strongly Agree/Agree & $56 \%$ & $52 \%$ & $59 \%$ \\
\hline
\end{tabular}

*Only participants with access to these system-level factors/resources were able to answer. For this reason the "N" for each set of questions is different. ${ }^{\wedge}$ This question was not included in the medical oncology survey. Abbreviations: TDF, Theoretical Domains Framework; GU, genitourinary; NACT, neoadjuvant chemotherapy; ACT, adjuvant chemotherapy; MIBC, muscle-invasive bladder cancer; MO, medical oncology. 
using a KT framework and guided by our earlier qualitative work in semi-structured interviews. Among urologists and MOs the TDF domains 'social and professional role' and 'social influences' were associated with higher referral/use chemotherapy. Common enablers within these domains relate to having local champions who advocate for use of NACT/ACT, routine referral from urology to $\mathrm{MO}$, and the belief that patients were generally accepting of chemotherapy. Conversely, a lack of local champions, and a perception among urologists that MOs do not treat the majority of referred patients with chemotherapy were identified as barriers. A proportion of participating urologists did not feel that it was their responsibility to refer all patients to $\mathrm{MO}$ and would only refer patients they deemed eligible for chemotherapy.

Factors related to 'environmental context and resources' were consistently identified in free-text responses as primary barriers/enablers to use of chemotherapy but this domain was not found to be associated with referral/use of NACT/ACT in the univariate model. Those who did practice in settings with MBCs, nurse navigators, and mandatory MO referral felt that these system-level resources were increased utilization of NACT/ACT.

Our study also highlights a substantial disconnect between outcomes anticipated by clinicians and outcomes achieved in routine practice. The five year overall survival estimates $(53 \%$ with cystectomy and $61 \%$ with NACT/cystectomy) are substantially higher than outcomes we have previously reported in the general population of Ontario (29\% and $25 \%$ respectively) [6]. Moreover, our data show tremendous variation in survival estimates between providers even within the same specialty. This gap between expected and actual outcomes is an area that warrants knowledge translation efforts to ensure that clinicians and patients have a clear understanding of disease prognosis. Consistent with prior literature in lung cancer, we also found that provider beliefs are associated with adoption of chemotherapy for bladder cancer [22].

To our knowledge, this is the first study to evaluate clinician perceived barriers and enablers to chemotherapy for bladder cancer using a KT framework. In seeking to identify and determine the prevalence of potential barriers and enablers influencing practice, use of the TDF minimizes the risk of neglecting important factors that may not be obvious at the outset of study design. The TDF can also guide the design and development process for future KT efforts. In addition, the current study included all three physician groups who manage MIBC; this allowed us to capture each group's unique cultures, beliefs and practices.

The low overall response and selection bias may limit the generalizability of the results. The fact that 9/10 urologists referred patients for chemotherapy also suggests that the study respondents likely represent a sub-group of practitioners who have already adopted NACT. Further, due to the small sample size our statistical power was limited for the conduct of multivariable analyses. Another limitation is that our study did not consider barriers/enablers to use of NACT/ACT from the patient perspective; this will form a parallel line of inquiry in the future. Finally, in an effort to quantify the association between TDF domains and use/referral of chemotherapy we used a pooled mean score approach across all questions within a specific domain. Pooling data across related questions in one domain may obscure a particularly strong barrier/enabler that was identified in a single question; to mitigate this we also carefully evaluated free-text responses regarding the greatest challenges/successes at their centre.

Interventions that have been designed to improve the uptake of research evidence into clinical practice in other disease settings have had limited and varied effects [23]. This may relate to a lack of explicit rationale for the intervention choice [16, 24]. Using a validated theoretical framework at the outset helped to ensure that our study design, conduct, and interpretation would optimize the design of a future intervention study $[16,17]$. The TDF allowed us to identify barriers/enablers within each domain can be now guide selection of the most appropriate $\mathrm{KT}$ intervention [25, 26]. For example, in the current study negative beliefs about the consequences of referral to $\mathrm{MO}$ for chemotherapy consultation by urologists may be modified by using influential peer opinion leaders at local sites or provision of information regarding patient outcomes. Finally, environmental changes to facilitate behavior change including the implementation of institutional policy mandating multidisciplinary collaboration may be required.

A four-step systematic approach for the development of theory-based behavioural change interventions has been described in the literature [16]. Our previous work has addressed step 1 of this process, revealing both low patterns of referral from urologists to MOs for NACT/ACT and low use of chemotherapy by MOs $[6,7]$. The current study addresses step 2 , identification of key barriers and enablers to the use 
of NACT/ACT among patients with bladder cancer. Steps 3 and 4 involve identifying, implementing, and measuring the impact of appropriate behavior change techniques; this represents a logical evolution of our research program.

In summary our study suggests that local urology and MO champions ('social and professional role') who advocate for NACT/ACT, systems-level factors ('environmental context/resources') that optimize multidisciplinary care, and patient engagement ('social influences') in the discussion of treatment options are critical factors that need to be considered in any future efforts to improve utilization of chemotherapy for MIBC. Our data also demonstrate a large gap between outcomes anticipated by clinicians and outcomes observed in routine practice. This has important implications for clinicians counselling patients regarding prognosis and treatment options. Findings from this study will be useful to policy and decision makers in the research planning, implementation and evaluation process.

\section{ACKNOWLEDGMENTS}

This work was funded by an operating grant from the Canadian Cancer Society Research Institute. Dr. Booth is funded as the Canada Research Chair in Population Cancer Care.

\section{DISCLOSURES}

The authors have no conflicts of interest.

\section{REFERENCES}

[1] Bellmunt J, Albiol S, Kataja V. Invasive bladder cancer: ESMO clinical recommendations for diagnosis, treatment and follow-up. Ann Oncol 2009;20(Suppl 4):79-80.

[2] Seah JA, Blais N, North S, et al. Neoadjuvant chemotherapy should be administered to fit patients with newly diagnosed, potentially resectable muscle-invasive urothelial cancer of the bladder (MIBC): A 2013 CAGMO Consensus Statement and Call for a Streamlined Referral Process. Can Urol Assoc J 2013;7:312-8.

[3] Milowsky MI, Rumble RB, Booth CM, et al. Guideline on Muscle-Invasive and Metastatic Bladder Cancer (European Association of Urology Guideline): American Society of Clinical Oncology Clinical Practice Guideline Endorsement. J Clin Oncol 2016;34:1945-52.

[4] Advanced Bladder Cancer Meta-analysis Collaboration. Adjuvant chemotherapy in invasive bladder cancer: A systematic review and meta-analysis of individual patient data. Eur Urol 2005;48:189-99.

[5] Booth CM, Tannock IF. Benefits of Adjuvant Chemotherapy for Bladder Cancer. JAMA Oncol 2015;1:727-8.
[6] Booth CM, Siemens DR, Li G, et al. Perioperative chemotherapy for muscle-invasive bladder cancer: A population-based outcomes study. Cancer 2014;120: 1630-8.

[7] Booth CM, Siemens DR, Peng Y, Mackillop WJ. Patterns of referral for perioperative chemotherapy among patients with muscle-invasive bladder cancer: A population-based study. Urol Oncol 2014;32:1200-8.

[8] David KA, Milowsky MI, Ritchey J, et al. Low incidence of perioperative chemotherapy for stage III bladder cancer 1998 to 2003: A report from the National Cancer Data Base. J Urol 2007;178:451-4.

[9] Schrag D, Mitra N, Xu F, et al. Cystectomy for muscle-invasive bladder cancer: Patterns and outcomes of care in the Medicare population. Urology 2005;65: 1118-25.

[10] Hermans TJ, Fransen van de Putte EE, Horenblas S, et al. Perioperative treatment and radical cystectomy for bladder cancer-a population based trend analysis of 10,338 patients in the Netherlands. Eur J Cancer 2016;54:18-26.

[11] Reardon ZD, Patel SG, Zaid HB, et al. Trends in the use of perioperative chemotherapy for localized and locally advanced muscle-invasive bladder cancer: A sign of changing tides. Eur Urol 2015;67:165-70.

[12] Patafio FM, Mackillop WJ, Feldman-Stewart D, et al. Why is perioperative chemotherapy for bladder cancer underutilized? Urol Oncol 2014;32:391-5.

[13] Apolo AB, Kim JW, Bochner BH, et al. Examining the management of muscle-invasive bladder cancer by medical oncologists in the United States. Urol Oncol 2014;32: 637-44.

[14] Hsu T, Black PC, Chi KN, et al. Treatment of muscle-invasive bladder cancer in Canada: A survey of genitourinary medical oncologists and urologists. Can Urol Assoc J 2014;8:309-16.

[15] Cowan NG, Chen Y, Downs TM, et al. Neoadjuvant chemotherapy use in bladder cancer: A survey of current practice and opinions. Adv Urol 2014;2014:746298.

[16] French SD, Green SE, O'Connor DA, et al. Developing theory-informed behaviour change interventions to implement evidence into practice: A systematic approach using the Theoretical Domains Framework. Implement Sci 2012;7:38.

[17] Cane J, O'Connor D, Michie S. Validation of the theoretical domains framework for use in behaviour change and implementation research. Implement Sci 2012;7:37.

[18] Francis JJ, O'Connor D, Curran J. Theories of behaviour change synthesised into a set of theoretical groupings: Introducing a thematic series on the theoretical domains framework. Implement Sci 2012;7:35.

[19] Dillman DA. Mail and Internet Surveys - The Tailored Design Method. Hoboken, N.J.: John Wiley and Sons, Inc. 2007.

[20] Seward K, Wolfenden L, Wiggers J, et al. Measuring implementation behaviour of menu guidelines in the childcare setting: Confirmatory factor analysis of a theoretical domains framework questionnaire (TDFQ). Int J Behav Nutr Phys Act 2017;14:45.

[21] Manikam L, Hoy A, Fosker H, et al. What drives junior doctors to use clinical practice guidelines? A national crosssectional survey of foundation doctors in England \& Wales. BMC Med Educ 2015;15:227.

[22] Raby B, Pater J, Mackillop WJ. Does knowledge guide practice? Another look at the management of non-small-cell lung cancer. J Clin Oncol 1995;13:1904-11. 
[23] Grimshaw JM, Thomas RE, MacLennan G, et al. Effectiveness and efficiency of guideline dissemination and implementation strategies. Health Technol Assess 2004;8:iii-72.

[24] Davies P, Walker AE, Grimshaw JM. A systematic review of the use of theory in the design of guideline dissemination and implementation strategies and interpretation of the results of rigorous evaluations. Implement Sci 2010;5:14.
[25] Michie S, Johnston M, Francis J, et al. From theory to intervention: Mapping theoretically derived behavioural determinants to behaviour change techniques. Applied Psychology 2008;57:660-80.

[26] Cochrane Collaboration. Effective Practice and Organization of Care (EPOC) Taxonomy 2015. Available at: https://epoc.cochrane.org/epoc-taxonomy, last accessed July 6, 2017. 
Appendix 1. Theoretical Domains Framework: Domains, Definitions and Constructs (Adapted from Cane, 2012)

\begin{tabular}{ll}
\hline Domain & Definition \\
\hline Knowledge & An awareness of the existence of something \\
Skills & An ability or proficiency acquired through practice \\
& \\
Social and & A coherent set of behaviours and displayed personal \\
Professional Role & qualities of an individual in a social or work setting
\end{tabular}
Constructs

Knowledge (including knowledge of condition

/scientific rationale)

Procedural knowledge

Knowledge of task environment

Skills

Skills development

Competence

Ability

Interpersonal skills

Practice

Skill assessment

Professional identity

Professional role

Social identity

Identity

Professional boundaries

Professional confidence

Group identity

Leadership

Organisational commitment

Beliefs about capabilities

\section{Beliefs about} consequences

Reinforcement

Intentions

Goals

Memory, attention and The ability to retain information, focus selectively on decision making

Acceptance of the truth, reality, or validity about an ability, talent, or facility that a person can put to constructive use

Acceptance of the truth, reality, or validity about outcomes of a behaviour in a given situation

Increasing the probability of a response by arranging a dependent relationship, or contingency, between the response and a given stimulus

A conscious decision to perform a behaviour or a resolve to act in a certain way

Mental representations of outcomes or end states that an individual wants to achieve

aspects of the environment and choose between two or more alternatives
Self-confidence

Perceived competence

Self-efficacy

Perceived behavioural control

Beliefs

Self-esteem

Empowerment

Professional confidence

Beliefs

Outcome expectancies

Characteristics of outcome expectancies Anticipated regret

Consequents

Rewards (proximal / distal, valued / not valued, probable / improbable)

Incentives

Punishment

Consequents

Reinforcement

Contingencies

Sanctions

Stability of intentions

Stages of change model

Transtheoretical model and stages of change

Goals (distal / proximal)

Goal priority

Goal / target setting

Goals (autonomous / controlled)

Action planning

Implementation intention

Memory

Attention

Attention control

Decision making

Cognitive overload / tiredness 
Appendix 1

(Continued)

\begin{tabular}{|c|c|c|}
\hline Domain & Definition & Constructs \\
\hline $\begin{array}{l}\text { Environmental } \\
\text { context and } \\
\text { resources }\end{array}$ & $\begin{array}{l}\text { Any circumstance of a person's situation or } \\
\text { environment that discourages or encourages the } \\
\text { development of skills and abilities, independence, } \\
\text { social competence, and adaptive behaviour }\end{array}$ & $\begin{array}{l}\text { Environmental stressors } \\
\text { Resources / material resources Organisational culture } \\
\quad \text { /climate } \\
\text { Salient events / critical incidents } \\
\text { Person } \times \text { environment interaction } \\
\text { Barriers and enablers }\end{array}$ \\
\hline Social Influences & $\begin{array}{l}\text { Those interpersonal processes that can cause individuals } \\
\text { to change their thoughts, feelings, or behaviours }\end{array}$ & $\begin{array}{l}\text { Social pressure } \\
\text { Social norms } \\
\text { Group conformity } \\
\text { Social comparisons } \\
\text { Group norms } \\
\text { Social support } \\
\text { Power } \\
\text { Intergroup conflict } \\
\text { Alienation } \\
\text { Group identity Modelling }\end{array}$ \\
\hline Emotion & $\begin{array}{l}\text { A complex reaction pattern, involving experiential, } \\
\text { behavioural, and physiological elements, by which } \\
\text { the individual attempts to deal with a personally } \\
\text { significant matter or event }\end{array}$ & $\begin{array}{l}\text { Fear } \\
\text { Anxiety } \\
\text { Affect } \\
\text { Stress } \\
\text { Depression } \\
\text { Positive / negative affect } \\
\text { Burn-out }\end{array}$ \\
\hline $\begin{array}{r}\text { Behavioural } \\
\text { regulation }\end{array}$ & $\begin{array}{l}\text { Anything aimed at managing or changing objectively } \\
\text { observed or measured actions }\end{array}$ & $\begin{array}{l}\text { Self-monitoring } \\
\text { Breaking habit } \\
\text { Action planning }\end{array}$ \\
\hline
\end{tabular}


Appendix 2. Barriers and enablers to the use of chemotherapy in MIBC by TDF Domain identified by urologists

\begin{tabular}{|c|c|c|c|}
\hline \multicolumn{4}{|l|}{ TDF Domain } \\
\hline Beliefs about Consequences & $\begin{array}{l}\text { Strongly } \\
\text { Disagree/ } \\
\text { Disagree }\end{array}$ & Neutral & $\begin{array}{l}\text { Strongly } \\
\text { Agree/ } \\
\text { Agree }\end{array}$ \\
\hline $\begin{array}{l}\text { I am confident in the published evidence regarding the benefits of } \\
\text { NACT in MIBC. }\end{array}$ & $4(4 \%)$ & $8(8 \%)$ & $94(89 \%)$ \\
\hline $\begin{array}{l}\text { I am confident in the published evidence regarding the benefits of } \\
\text { ACT in MIBC. }\end{array}$ & $12(11 \%)$ & $33(31 \%)$ & $61(58 \%)$ \\
\hline I think the magnitude of benefit with NACT is clinically important. & $5(5 \%)$ & $14(13 \%)$ & $87(82 \%)$ \\
\hline I think the magnitude of benefit with ACT is clinically important. & $20(19 \%)$ & $42(40 \%)$ & $44(42 \%)$ \\
\hline $\begin{array}{l}\text { In absence of higher risk disease features (i.e. lymphovascular } \\
\text { invasion, positive nodes, etc.), patients with MIBC do not benefit } \\
\text { from NACT and should proceed directly to cystectomy.* }\end{array}$ & $80(75 \%)$ & $18(17 \%)$ & $8(8 \%)$ \\
\hline $\begin{array}{l}\text { I am not sure that MIBC patients benefit from treatment with } \\
\text { NACT.* }\end{array}$ & $85(80 \%)$ & $14(13 \%)$ & $7(7 \%)$ \\
\hline I am not sure that MIBC patients benefit from treatment with ACT.* & $44(42 \%)$ & $27(25 \%)$ & $35(33 \%)$ \\
\hline $\begin{array}{l}\text { I am concerned about the delay in surgery when medical } \\
\text { oncologists give NACT.* }\end{array}$ & $57(54 \%)$ & $22(21 \%)$ & $27(25 \%)$ \\
\hline $\begin{array}{l}\text { I believe that my referral to medical oncology for chemotherapy } \\
\text { increases the patient's likelihood of cure. }\end{array}$ & $2(2 \%)$ & $12(11 \%)$ & $92(87 \%)$ \\
\hline $\begin{array}{l}\text { I am concerned about toxicity from chemotherapy in MIBC patients } \\
\text { which affects my decisions to refer to medical oncology.* }\end{array}$ & $53(50 \%)$ & $15(14 \%)$ & $38(36 \%)$ \\
\hline Memory, attention and decision making skills & $\begin{array}{l}\text { Strongly } \\
\text { Disagree/ } \\
\text { Disagree }\end{array}$ & Neutral & $\begin{array}{l}\text { Strongly } \\
\text { Agree/ } \\
\text { Agree }\end{array}$ \\
\hline $\begin{array}{l}\text { I feel confident determining who is and who is not a chemotherapy } \\
\text { candidate. }\end{array}$ & $29(28 \%)$ & $29(28 \%)$ & $45(44 \%)$ \\
\hline $\begin{array}{l}\text { I sometimes forget that NACT/ACT is an option for my MIBC } \\
\text { patients.* }\end{array}$ & $95(92 \%)$ & $2(2 \%)$ & $6(6 \%)$ \\
\hline Social and professional role & $\begin{array}{l}\text { Strongly } \\
\text { Disagree/ } \\
\text { Disagree }\end{array}$ & Neutral & $\begin{array}{l}\text { Strongly } \\
\text { Agree/ } \\
\text { Agree }\end{array}$ \\
\hline $\begin{array}{l}\text { Our centre has medical oncologists who function as NACT/ACT } \\
\text { champions and advocate for treatment in patients with MIBC }\end{array}$ & $15(15 \%)$ & $26(27 \%)$ & $56(58 \%)$ \\
\hline $\begin{array}{l}\text { It is my responsibility to select which patients with MIBC are } \\
\text { suitable chemotherapy candidates and refer only those candidates } \\
\text { on to medical oncology.* }\end{array}$ & $35(36 \%)$ & $17(18 \%)$ & $45(46 \%)$ \\
\hline $\begin{array}{l}\text { It is my responsibility to have a discussion about the role of } \\
\text { chemotherapy with all MIBC patients. }\end{array}$ & $4(4 \%)$ & $3(3 \%)$ & $90(93 \%)$ \\
\hline $\begin{array}{l}\text { It is my responsibility to refer all patients with MIBC to medical } \\
\text { oncology. }\end{array}$ & $16(16 \%)$ & $14(14 \%)$ & $67(69 \%)$ \\
\hline $\begin{array}{l}\text { I would not refer a MIBC patient to medical oncology if that patient } \\
\text { is clearly not a chemotherapy candidate.* }\end{array}$ & $23(24 \%)$ & $17(18 \%)$ & $57(59 \%)$ \\
\hline $\begin{array}{l}\text { Our medical oncologists treat the majority of MIBC patient } \\
\text { referrals with chemotherapy. }\end{array}$ & $20(21 \%)$ & $12(12 \%)$ & $65(67 \%)$ \\
\hline $\begin{array}{l}\text { I am confident our medical oncologists treat MIBC patients } \\
\text { appropriately. }\end{array}$ & $5(5 \%)$ & $14(14 \%)$ & $78(80 \%)$ \\
\hline Environmental context and resources & $\begin{array}{l}\text { Strongly } \\
\text { Disagree/ } \\
\text { Disagree }\end{array}$ & Neutral & $\begin{array}{l}\text { Strongly } \\
\text { Agree/ } \\
\text { Agree }\end{array}$ \\
\hline $\begin{array}{l}\text { I have access to medical oncology which makes patient referral } \\
\text { easy. }\end{array}$ & $3(3 \%)$ & $3(3 \%)$ & $91(94 \%)$ \\
\hline $\begin{array}{l}\text { In the last } 3 \text { years, more MIBC patients are receiving NACT at our } \\
\text { centre than before. }\end{array}$ & $5(5 \%)$ & $13(13 \%)$ & $79(81 \%)$ \\
\hline $\begin{array}{l}\text { It is more difficult for urologists at community centres to refer } \\
\text { patients to medical oncology than it is for urologists at } \\
\text { comprehensive cancer centres.* }\end{array}$ & $46(47 \%)$ & $14(14 \%)$ & $37(38 \%)$ \\
\hline
\end{tabular}


Appendix 2

(Continued)

\begin{tabular}{|c|c|c|c|c|}
\hline Environmental context and resources & $\begin{array}{l}\text { Strongly } \\
\text { Disagree/ } \\
\text { Disagree }\end{array}$ & Neutral & $\begin{array}{l}\text { Strongly } \\
\text { Agree/ } \\
\text { Agree }\end{array}$ & \\
\hline $\begin{array}{l}\text { My institution has barriers which makes communication between } \\
\text { urology and medical oncology difficult.* }\end{array}$ & $71(73 \%)$ & $4(4 \%)$ & $5(5 \%)$ & $17(18 \%)$ \\
\hline $\begin{array}{l}\text { There is a geographic barrier between my institution and where } \\
\text { medical oncology is located that makes it difficult to get patients } \\
\text { in for consultation.* }\end{array}$ & $84(87 \%)$ & $6(6 \%)$ & $6(6 \%)$ & $1(1 \%)$ \\
\hline $\begin{array}{l}\text { Our multi-disciplinary clinic for bladder cancer has resulted in } \\
\text { more patients being treated with NACT/ACT. }\end{array}$ & $1(1 \%)$ & $4(4 \%)$ & $18(19 \%)$ & $74(76 \%)$ \\
\hline $\begin{array}{l}\text { Our GU multidisciplinary case conferences are well attended by } \\
\text { urology. }\end{array}$ & $13(13 \%)$ & $6(6 \%)$ & $62(64 \%)$ & $16(16 \%)$ \\
\hline $\begin{array}{l}\text { Our GU multidisciplinary case conferences are well attended by } \\
\text { medical oncology }\end{array}$ & $5(5 \%)$ & $1(1 \%)$ & $75(77 \%)$ & $16(16 \%)$ \\
\hline $\begin{array}{l}\text { Our GU multidisciplinary case conferences are well attended by } \\
\text { radiation oncology }\end{array}$ & $2(2 \%)$ & $6(6 \%)$ & $73(75 \%)$ & $16(16 \%)$ \\
\hline $\begin{array}{l}\text { Our GU multidisciplinary case conferences are helpful to discuss } \\
\text { treatment options for patients with MIBC. }\end{array}$ & $1(1 \%)$ & $16(16 \%)$ & $64(66 \%)$ & $16(16 \%)$ \\
\hline $\begin{array}{l}\text { Q33 Our GU multidisciplinary case conferences result in a larger } \\
\text { proportion of MIBC patients receiving NACT/ACT. }\end{array}$ & $9(9 \%)$ & $18(19 \%)$ & $54(56 \%)$ & $16(16 \%)$ \\
\hline $\begin{array}{l}\text { More patients with MIBC are receiving NACT/ACT at our centre } \\
\text { since we instituted a policy that patients are to be referred to } \\
\text { medical oncology }\end{array}$ & $0(0 \%)$ & $2(2 \%)$ & $4(4 \%)$ & $88(91 \%)$ \\
\hline At our centre, we do not use NACT for MIBC patients.* & $78(80 \%)$ & $0(0 \%)$ & $2(2 \%)$ & $17(18 \%)$ \\
\hline At our centre, we do not use ACT for MIBC patients.* & $67(69 \%)$ & $7(7 \%)$ & $6(6 \%)$ & $17(18 \%)$ \\
\hline $\begin{array}{l}\text { The percentage of MIBC patients at our centre who get } \\
\text { NACT/ACT increased after we obtained GU MO expertise. }\end{array}$ & $6(6 \%)$ & $23(24 \%)$ & $37(38 \%)$ & $31(32 \%)$ \\
\hline $\begin{array}{l}\text { Having access to GU medical oncologists has increased my patient } \\
\text { referral for NACT/ACT consultation. }\end{array}$ & $9(9 \%)$ & $18(19 \%)$ & $55(57 \%)$ & $15(15 \%)$ \\
\hline Social influences & $\begin{array}{l}\text { Strongly } \\
\text { Disagree/ } \\
\text { Disagree }\end{array}$ & Neutral & $\begin{array}{l}\text { Strongly } \\
\text { Agree/ } \\
\text { Agree }\end{array}$ & \\
\hline $\begin{array}{l}\text { My patients are generally accepting of chemotherapy as part of } \\
\text { their treatment plan. }\end{array}$ & $8(8 \%)$ & $14(15 \%)$ & $74(77 \%)$ & \\
\hline $\begin{array}{l}\text { Many of my MIBC patients refuse to speak with medical oncology } \\
\text { about chemotherapy options.* }\end{array}$ & $73(76 \%)$ & $8(8 \%)$ & $15(16 \%)$ & \\
\hline $\begin{array}{l}\text { If a patient refuses chemotherapy, I will not encourage them further } \\
\text { to speak with medical oncology.* }\end{array}$ & $47(49 \%)$ & $14(15 \%)$ & $35(36 \%)$ & \\
\hline Beliefs about capabilities & $\begin{array}{l}\text { Strongly } \\
\text { Disagree/ } \\
\text { Disagree }\end{array}$ & Neutral & $\begin{array}{l}\text { Strongly } \\
\text { Agree/ } \\
\text { Agree }\end{array}$ & \\
\hline $\begin{array}{l}\text { I am confident our medical oncologists treat MIBC patients } \\
\text { appropriately. }\end{array}$ & $5(5 \%)$ & $14(13 \%)$ & $87(82 \%)$ & \\
\hline $\begin{array}{l}\text { I am able to discuss the risks and benefits of NACT with my MIBC } \\
\text { patients. }\end{array}$ & $13(12 \%)$ & $25(24 \%)$ & $68(64 \%)$ & \\
\hline $\begin{array}{l}\text { I am able to discuss the risks and benefits of ACT with my MIBC } \\
\text { patients. }\end{array}$ & $20(19 \%)$ & $24(23 \%)$ & $62(58 \%)$ & \\
\hline
\end{tabular}

Totals may exceed $100 \%$ due to rounding. $*^{*}$ indicates a survey question that was reversed in the domain score analysis. ${ }^{\wedge}$ Only participants with access to these system-level factors/resources were able to answer. 
Appendix 3. Barriers and enablers to the use of chemotherapy in MIBC by TDF Domain identified by medical oncologists

\begin{tabular}{|c|c|c|c|}
\hline TDF Domain & & & \\
\hline Beliefs about Consequences & $\begin{array}{l}\text { Strongly } \\
\text { Disagree/ } \\
\text { Disagree }\end{array}$ & Neutral & $\begin{array}{l}\text { Strongly } \\
\text { Agree/ } \\
\text { Agree }\end{array}$ \\
\hline $\begin{array}{l}\text { I am confident in the published evidence regarding the benefits of } \\
\text { NACT in MIBC. }\end{array}$ & $2(4 \%)$ & $3(6 \%)$ & $42(89 \%)$ \\
\hline $\begin{array}{l}\text { I am confident in the published evidence regarding the benefits of } \\
\text { ACT in MIBC. }\end{array}$ & $6(13 \%)$ & $25(53 \%)$ & $16(34 \%)$ \\
\hline $\begin{array}{l}\text { I think the magnitude of benefit with NACT in the setting of MIBC } \\
\text { is clinically important. }\end{array}$ & $0(0 \%)$ & $2(4 \%)$ & $45(96 \%)$ \\
\hline $\begin{array}{l}\text { I think the magnitude of benefit with ACT in the setting of MIBC is } \\
\text { clinically important. }\end{array}$ & $2(4 \%)$ & $24(51 \%)$ & $21(45 \%)$ \\
\hline $\begin{array}{l}\text { In absence of higher risk disease features (i.e. lymphovascular } \\
\text { invasion, positive nodes, etc.), patients with MIBC do not benefit } \\
\text { from NACT and should proceed directly to cystectomy.* }\end{array}$ & $41(87 \%)$ & $4(9 \%)$ & $2(4 \%)$ \\
\hline $\begin{array}{l}\text { I am not sure that MIBC patients benefit from treatment with } \\
\text { NACT.* }\end{array}$ & $42(89 \%)$ & $3(6 \%)$ & $2(4 \%)$ \\
\hline I am not sure that MIBC patients benefit from treatment with ACT.* & $17(36 \%)$ & $11(23 \%)$ & $19(40 \%)$ \\
\hline $\begin{array}{l}\text { I am concerned about delaying surgery by giving MIBC patients } \\
\text { NACT.* }\end{array}$ & $41(87 \%)$ & $4(9 \%)$ & $2(4 \%)$ \\
\hline $\begin{array}{l}\text { I think that treating MIBC patients with NACT improves patient } \\
\text { survival. }\end{array}$ & $0(0 \%)$ & $0(0 \%)$ & $47(100 \%)$ \\
\hline $\begin{array}{l}\text { I think that treating MIBC patients with ACT improves patient } \\
\text { survival }\end{array}$ & $3(6 \%)$ & $21(45 \%)$ & $23(49 \%)$ \\
\hline $\begin{array}{l}\text { I am concerned about toxicity from chemotherapy in MIBC } \\
\text { patients which affects my decisions to treat.* }\end{array}$ & $12(26 \%)$ & $10(21 \%)$ & $25(53 \%)$ \\
\hline Memory, attention and decision making skills & $\begin{array}{l}\text { Strongly } \\
\text { Disagree/ } \\
\text { Disagree }\end{array}$ & Neutral & $\begin{array}{l}\text { Strongly } \\
\text { Agree/ } \\
\text { Agree }\end{array}$ \\
\hline $\begin{array}{l}\text { I am confident that I can appropriately assess whether a patient with } \\
\text { MIBC is medically eligible for NACT/ACT. }\end{array}$ & $1(2 \%)$ & $0(0 \%)$ & $46(98 \%)$ \\
\hline Social and professional role & $\begin{array}{l}\text { Strongly } \\
\text { Disagree/ } \\
\text { Disagree }\end{array}$ & Neutral & $\begin{array}{l}\text { Strongly } \\
\text { Agree/ } \\
\text { Agree }\end{array}$ \\
\hline $\begin{array}{l}\text { The urologists I work with who perform cystectomy consult with } \\
\text { me about chemotherapy options for all MIBC patients. }\end{array}$ & $6(13 \%)$ & $9(19 \%)$ & $32(68 \%)$ \\
\hline $\begin{array}{l}\text { Urologists I work with who perform cystectomy routinely refer } \\
\text { patients with MIBC to medical oncology for chemotherapy } \\
\text { consultation. }\end{array}$ & $4(9 \%)$ & $4(9 \%)$ & $39(83 \%)$ \\
\hline $\begin{array}{l}\text { Urologists I work with who perform cystectomy select which } \\
\text { patients with MIBC are suitable chemotherapy candidates and } \\
\text { refer only those candidates to medical oncology.* }\end{array}$ & $19(40 \%)$ & $10(21 \%)$ & $18(38 \%)$ \\
\hline $\begin{array}{l}\text { Urologists should not refer a MIBC patient to medical oncology if } \\
\text { that patient is clearly not a chemotherapy candidate.* }\end{array}$ & $28(60 \%)$ & $7(15 \%)$ & $12(26 \%)$ \\
\hline I treat the majority of MIBC patient referrals with NACT. & $2(4 \%)$ & $5(11 \%)$ & $40(85 \%)$ \\
\hline I treat the majority of MIBC patient referrals with ACT. & $31(66 \%)$ & $11(23 \%)$ & $5(11 \%)$ \\
\hline $\begin{array}{l}\text { Our centre has urologists who are NACT/ACT champions and } \\
\text { advocate for treatment in patients with MIBC. }\end{array}$ & $5(11 \%)$ & $7(15 \%)$ & $35(74 \%)$ \\
\hline $\begin{array}{l}\text { Our centre has medical oncologists who function as NACT/ACT } \\
\text { champions and advocate for treatment in patients with MIBC. }\end{array}$ & $3(6 \%)$ & $5(11 \%)$ & $39(83 \%)$ \\
\hline Environmental context and resources & $\begin{array}{l}\text { Strongly } \\
\text { Disagree/ } \\
\text { Disagree }\end{array}$ & Neutral & $\begin{array}{c}\text { Strongly } \\
\text { Agree/ } \\
\text { Agree }\end{array}$ \\
\hline $\begin{array}{l}\text { My institution has barriers which makes communication between } \\
\text { urology and medical oncology difficult.* }\end{array}$ & $36(77 \%)$ & $3(6 \%)$ & $8(17 \%)$ \\
\hline $\begin{array}{l}\text { In the last } 3 \text { years, more MIBC patients are receiving NACT at our } \\
\text { centre than before. }\end{array}$ & $4(9 \%)$ & $15(32 \%)$ & $28(60 \%)$ \\
\hline
\end{tabular}


Appendix 3

(Continued)

\begin{tabular}{|c|c|c|c|c|}
\hline Environmental context and resources & $\begin{array}{l}\text { Strongly } \\
\text { Disagree/ } \\
\text { Disagree }\end{array}$ & Neutral & $\begin{array}{r}\text { Strongly } \\
\text { Agree/ } \\
\text { Agree }\end{array}$ & \\
\hline $\begin{array}{l}\text { Our GU multidisciplinary case conferences are helpful to discuss } \\
\text { treatment options for patients with MIBC }\end{array}$ & $2(4 \%)$ & $4(9 \%)$ & $37(79 \%)$ & $4(9 \%)$ \\
\hline $\begin{array}{l}\text { Our GU multidisciplinary case conferences are well attended by } \\
\text { urology }\end{array}$ & $6(13 \%)$ & $5(11 \%)$ & $32(68 \%)$ & $4(9 \%)$ \\
\hline $\begin{array}{l}\text { Our GU multidisciplinary case conferences are well attended by } \\
\text { medical oncology }\end{array}$ & $0(0 \%)$ & $0(0 \%)$ & $43(91 \%)$ & $4(9 \%)$ \\
\hline $\begin{array}{l}\text { Our GU multidisciplinary case conferences are well attended by } \\
\text { radiation oncology }\end{array}$ & $1(2 \%)$ & $1(2 \%)$ & $41(87 \%)$ & $4(9 \%)$ \\
\hline $\begin{array}{l}\text { Our multidisciplinary clinic for bladder cancer has resulted in more } \\
\text { patients being treated with NACT/ACT }\end{array}$ & $1(2 \%)$ & $1(2 \%)$ & $9(19 \%)$ & $36(77 \%)$ \\
\hline $\begin{array}{l}\text { More patients with } \mathrm{MIBC} \text { are receiving NACT/ACT at our centre } \\
\text { since we instituted a policy that patients are to be referred to } \\
\text { medical oncology }\end{array}$ & $0(0 \%)$ & $2(4 \%)$ & $6(13 \%)$ & $39(83 \%)$ \\
\hline $\begin{array}{l}\text { The percentage of MIBC patients at our centre who get } \\
\text { NACT/ACT increased after we obtained GU MO expertise. }\end{array}$ & $4(9 \%)$ & $16(34 \%)$ & $22(47 \%)$ & $5(11 \%)$ \\
\hline $\begin{array}{l}\text { There is a geographic barrier between my institution and where the } \\
\text { urologists are located that makes it difficult to get patients in for } \\
\text { consultation.* }\end{array}$ & $33(70 \%)$ & $3(6 \%)$ & $11(23 \%)$ & \\
\hline $\begin{array}{l}\text { It is more difficult for urologists at community centres to refer } \\
\text { patients to medical oncology than it is for urologists at } \\
\text { comprehensive cancer centres.* }\end{array}$ & $24(51 \%)$ & $8(17 \%)$ & $15(32 \%)$ & \\
\hline Social influences & $\begin{array}{l}\text { Strongly } \\
\text { Disagree/ } \\
\text { Disagree }\end{array}$ & Neutral & $\begin{array}{l}\text { Strongly } \\
\text { Agree/ } \\
\text { Agree }\end{array}$ & \\
\hline $\begin{array}{l}\text { My patients are generally accepting of chemotherapy as part of } \\
\text { their treatment plan. }\end{array}$ & $1(2 \%)$ & $5(11 \%)$ & $41(87 \%)$ & \\
\hline $\begin{array}{l}\text { Many patients refuse referral to medical oncology to discuss } \\
\text { chemotherapy options.* }\end{array}$ & $33(70 \%)$ & $13(28 \%)$ & $1(2 \%)$ & \\
\hline Behavioural regulation & $\begin{array}{l}\text { Strongly } \\
\text { Disagree/ } \\
\text { Disagree }\end{array}$ & Neutral & $\begin{array}{l}\text { Strongly } \\
\text { Agree/ } \\
\text { Agree }\end{array}$ & \\
\hline $\begin{array}{l}\text { Urologists I work with who perform cystectomy routinely refer } \\
\text { patients with MIBC to medical oncology for chemotherapy } \\
\text { consultation. }\end{array}$ & $4(9 \%)$ & $4(9 \%)$ & $39(83 \%)$ & \\
\hline I treat the majority of MIBC patient referrals with NACT. & $2(4 \%)$ & $5(11 \%)$ & $40(85 \%)$ & \\
\hline I treat the majority of MIBC patient referrals with ACT. & $31(66 \%)$ & $11(23 \%)$ & $5(11 \%)$ & \\
\hline Knowledge & $\begin{array}{c}\text { Strongly } \\
\text { Disagree/ } \\
\text { Disagree }\end{array}$ & Neutral & $\begin{array}{c}\text { Strongly } \\
\text { Agree/ } \\
\text { Agree }\end{array}$ & \\
\hline $\begin{array}{l}\text { The urologists I work with who perform cystectomy are } \\
\text { knowledgeable about the use of NACT/ACT for MIBC patients. }\end{array}$ & $3(6 \%)$ & $5(11 \%)$ & $39(83 \%)$ & \\
\hline $\begin{array}{l}\text { The urologists I work with who perform cystectomy consult with } \\
\text { me about chemotherapy options for all MIBC patients. }\end{array}$ & $6(13 \%)$ & $9(19 \%)$ & $32(68 \%)$ & \\
\hline Beliefs about capabilities & $\begin{array}{c}\text { Strongly } \\
\text { Disagree/ } \\
\text { Disagree }\end{array}$ & Neutral & $\begin{array}{c}\text { Strongly } \\
\text { Agree/ } \\
\text { Agree }\end{array}$ & \\
\hline $\begin{array}{l}\text { The urologists I work with who perform cystectomy are } \\
\text { knowledgeable about the use of NACT/ACT for MIBC patients. }\end{array}$ & $3(6 \%)$ & $5(11 \%)$ & $39(83 \%)$ & \\
\hline
\end{tabular}

Totals may exceed $100 \%$ due to rounding. *indicates a survey question that was reversed in the domain score analysis. ${ }^{\wedge}$ Only participants with access to these system-level factors/resources were able to answer. 
Appendix 4. Barriers and enablers to the use of chemotherapy in MIBC by TDF Domain identified by radiation oncologists

\begin{tabular}{|c|c|c|c|c|}
\hline TDF Domain & & & & \\
\hline Beliefs about Consequences & $\begin{array}{l}\text { Strongly } \\
\text { Disagree/ } \\
\text { Disagree }\end{array}$ & Neutral & $\begin{array}{l}\text { Strongly } \\
\text { Agree/ } \\
\text { Agree }\end{array}$ & \\
\hline $\begin{array}{l}\text { I am confident in the published evidence regarding the benefits of } \\
\text { NACT in MIBC. }\end{array}$ & $3(8 \%)$ & $2(5 \%)$ & $35(88 \%)$ & \\
\hline $\begin{array}{l}\text { I am confident in the published evidence regarding the benefits of } \\
\text { ACT in MIBC. }\end{array}$ & $5(13 \%)$ & $17(43 \%)$ & $18(45 \%)$ & \\
\hline I think the magnitude of benefit with NACT is clinically important. & $2(5 \%)$ & $2(5 \%)$ & $36(90 \%)$ & \\
\hline I think the magnitude of benefit with ACT is clinically important. & $6(15 \%)$ & $13(33 \%)$ & $21(53 \%)$ & \\
\hline $\begin{array}{l}\text { I believe that my referral to medical oncology for chemotherapy } \\
\text { increases the patient's likelihood of cure. }\end{array}$ & $1(3 \%)$ & $5(13 \%)$ & $34(85 \%)$ & \\
\hline $\begin{array}{l}\text { Urologists I work with who perform cystectomy are not confident } \\
\text { that patients with MIBC benefit from NACT.* }\end{array}$ & $29(73 \%)$ & $7(18 \%)$ & $4(10 \%)$ & \\
\hline $\begin{array}{l}\text { Urologists I work with who perform cystectomy are not confident } \\
\text { that patients with MIBC benefit from ACT.* }\end{array}$ & $9(23 \%)$ & $24(60 \%)$ & $7(18 \%)$ & \\
\hline $\begin{array}{l}\text { Urologists I work with who perform cystectomy think that in } \\
\text { absence of higher risk disease features (i.e. lymphovascular } \\
\text { invasion, positive nodes, etc.), patients with MIBC do not benefit } \\
\text { from NACT and should proceed directly to cystectomy.* }\end{array}$ & $20(50 \%)$ & $12(30 \%)$ & $8(20 \%)$ & \\
\hline $\begin{array}{l}\text { The urologists I work with who perform cystectomy are concerned } \\
\text { that referral to medical oncology delays surgery. }{ }^{*}\end{array}$ & $20(50 \%)$ & $14(35 \%)$ & $6(15 \%)$ & \\
\hline Memory, attention and decision making skills & $\begin{array}{l}\text { Strongly } \\
\text { Disagree/ } \\
\text { Disagree }\end{array}$ & Neutral & $\begin{array}{l}\text { Strongly } \\
\text { Agree/ } \\
\text { Agree }\end{array}$ & \\
\hline $\begin{array}{l}\text { I feel confident determining who is and who is not a chemotherapy } \\
\text { candidate. }\end{array}$ & $20(50 \%)$ & $8(20 \%)$ & $12(30 \%)$ & \\
\hline $\begin{array}{l}\text { Even if I am confident that an MIBC patient is not eligible for } \\
\text { NACT/ACT I still refer to medical oncology for the discussion if } \\
\text { not referred by urology. }\end{array}$ & $9(23 \%)$ & $9(23 \%)$ & $22(55 \%)$ & \\
\hline Social and professional role & $\begin{array}{l}\text { Strongly } \\
\text { Disagree/ } \\
\text { Disagree }\end{array}$ & Neutral & $\begin{array}{l}\text { Strongly } \\
\text { Agree/ } \\
\text { Agree }\end{array}$ & \\
\hline $\begin{array}{l}\text { It is my responsibility to refer all patients with MIBC to medical } \\
\text { oncology if not done so by urology }\end{array}$ & $5(13 \%)$ & $3(8 \%)$ & $32(80 \%)$ & \\
\hline $\begin{array}{l}\text { Urologists I work with who perform cystectomy do not routinely } \\
\text { refer MIBC patients to medical oncology for chemotherapy } \\
\text { consultation. }\end{array}$ & $26(65 \%)$ & $7(18 \%)$ & $7(18 \%)$ & \\
\hline $\begin{array}{l}\text { It is my responsibility to select which patients with MIBC are } \\
\text { suitable chemotherapy candidates and refer only those candidates } \\
\text { to medical oncology.* }\end{array}$ & $24(60 \%)$ & $8(20 \%)$ & $8(20 \%)$ & \\
\hline $\begin{array}{l}\text { Our centre has urologists who are NACT/ACT champions and } \\
\text { advocate for chemotherapy in patients with MIBC. }\end{array}$ & $7(18 \%)$ & $9(23 \%)$ & $24(60 \%)$ & \\
\hline $\begin{array}{l}\text { Our centre has medical oncologists who are NACT/ACT champions } \\
\text { and advocate for chemotherapy in patients with MIBC }\end{array}$ & $2(5 \%)$ & $4(10 \%)$ & $34(85 \%)$ & \\
\hline Environmental context and resources & $\begin{array}{c}\text { Strongly } \\
\text { Disagree/ } \\
\text { Disagree }\end{array}$ & Neutral & $\begin{array}{c}\text { Strongly } \\
\text { Agree/ } \\
\text { Agree }\end{array}$ & $\mathrm{N} / \mathrm{A}^{\wedge}$ \\
\hline $\begin{array}{l}\text { There are communication barriers between radiation oncology and } \\
\text { medical oncology at our centre.* }\end{array}$ & $37(93 \%)$ & $1(3 \%)$ & $2(5 \%)$ & \\
\hline $\begin{array}{l}\text { There are communication barriers between radiation oncology and } \\
\text { urology at our centre.* }\end{array}$ & $26(65 \%)$ & $4(10 \%)$ & $10(25 \%)$ & \\
\hline $\begin{array}{l}\text { There are communication barriers between urology and medical } \\
\text { oncology at our centre.* }\end{array}$ & $27(68 \%)$ & $9(23 \%)$ & $4(10 \%)$ & \\
\hline $\begin{array}{l}\text { In the last } 3 \text { years, more MIBC patients are receiving NACT at our } \\
\text { centre than before. }\end{array}$ & $2(5 \%)$ & $15(38 \%)$ & $23(58 \%)$ & \\
\hline $\begin{array}{l}\text { Our multidisciplinary case conferences are helpful to discuss } \\
\text { treatment options for patients with MIBC }\end{array}$ & $2(5 \%)$ & $4(10 \%)$ & $33(83 \%)$ & $1(3 \%)$ \\
\hline
\end{tabular}


Appendix 4

(Continued)

\begin{tabular}{|c|c|c|c|c|}
\hline Environmental context and resources & $\begin{array}{l}\text { Strongly } \\
\text { Disagree/ } \\
\text { Disagree }\end{array}$ & Neutral & $\begin{array}{l}\text { Strongly } \\
\text { Agree/ } \\
\text { Agree }\end{array}$ & \\
\hline $\begin{array}{l}\text { Our multidisciplinary case conferences are well attended by } \\
\text { urology }\end{array}$ & $7(18 \%)$ & $2(5 \%)$ & $30(75 \%)$ & $1(3 \%)$ \\
\hline $\begin{array}{l}\text { Our multidisciplinary case conferences are well attended by } \\
\text { medical oncology }\end{array}$ & $1(3 \%)$ & $1(3 \%)$ & $37(93 \%)$ & $1(3 \%)$ \\
\hline $\begin{array}{l}\text { Our multidisciplinary case conferences are well attended by } \\
\text { radiation oncology }\end{array}$ & $1(3 \%)$ & $3(8 \%)$ & $35(88 \%)$ & $1(3 \%)$ \\
\hline $\begin{array}{l}\text { Our multidisciplinary case conferences result in a larger proportion } \\
\text { of MIBC patients receiving NACT/ACT }\end{array}$ & $5(13 \%)$ & $14(35 \%)$ & $20(50 \%)$ & $1(3 \%)$ \\
\hline $\begin{array}{l}\text { Our multidisciplinary clinic for MIBC patients has resulted in more } \\
\text { patients being treated with NACT/ACT }\end{array}$ & $0(0 \%)$ & $1(3 \%)$ & $7(18 \%)$ & $32(80 \%)$ \\
\hline $\begin{array}{l}\text { More patients with MIBC are receiving NACT/ACT at our centre } \\
\text { since we instituted a policy that patients are to be seen by } \\
\text { medical oncology }\end{array}$ & $0(0 \%)$ & $2(5 \%)$ & $9(23 \%)$ & $29(73 \%)$ \\
\hline $\begin{array}{l}\text { The percentage of MIBC patients at our centre who get } \\
\text { NACT/ACT increased after we obtained GU MO expertise }\end{array}$ & $1(3 \%)$ & $15(38 \%)$ & $23(58 \%)$ & $1(3 \%)$ \\
\hline $\begin{array}{l}\text { Having access to GU medical oncologists has increased my patient } \\
\text { referral for NACT/ACT consultation. }\end{array}$ & $4(10 \%)$ & $13(33 \%)$ & $23(58 \%)$ & \\
\hline Behavioural regulation & $\begin{array}{l}\text { Strongly } \\
\text { Disagree/ } \\
\text { Disagree }\end{array}$ & Neutral & $\begin{array}{l}\text { Strongly } \\
\text { Agree/ } \\
\text { Agree }\end{array}$ & \\
\hline $\begin{array}{l}\text { Urologists I work with who perform cystectomy do not routinely } \\
\text { refer MIBC patients to medical oncology for chemotherapy } \\
\text { consultation. }\end{array}$ & $27(66 \%)$ & $7(17 \%)$ & $7(17 \%)$ & \\
\hline
\end{tabular}

Totals may exceed $100 \%$ due to rounding. *indicates a survey question that was reversed in the domain score analysis. ${ }^{\wedge}$ Only participants with access to these system-level factors/resources were able to answer. 